\title{
The Role of Financial Openness in Triggering Bank Risk and Efficiency: Empirical Evidence from Pakistan
}

\author{
MUHAMMAD QASIM \\ Lahore Business School, The University of Lahore, Pakistan. \\ Email: qasim4890@yahoo.com \\ IRFAN AZIZ \\ Lahore Business School, The University of Lahore, Pakistan. \\ Email: arfanraj2@gmail.com \\ MUHAMMAD NAVEED \\ Department of Management Studies, Bahria University Islamabad. \\ Email: Qm.naveed@outlook.com
}

\begin{abstract}
The purpose of the study is to find out empirically the interrelation among three main variables financial openness, efficiency and risk of commercial banks working in Pakistan while controlling for other countryspecific variables. The study has been conducted to investigate the potential direct impact of financial openness and risk on the profit efficiency of commercial banks and to further check that whether the efficiency of domestic commercial banks is indirectly affected by financial openness through a change in bank risk. The efficiency of all commercial banks is separately calculated and analysed to find out which bank is the most efficient and which has the lowest efficiency score. The dataset consists of 13 private commercial banks working in Pakistan, covering the period from 2008 - 2018. System GMM is used along with the Auto Regressive Distributive Lagged model to find out the prevailing impact of financial openness and bank risk on the profit efficiency of domestic commercial banks of Pakistan. Efficiency score is calculated through Stochastic Frontier Approach using Battese and Coelli (1995) model. The main finding of the study reveals that financial openness has a direct negative impact on the profit efficiency of domestic commercial banks working in Pakistan. Risk has no direct impact on profit efficiency, however, financial openness has a positive association with risk, hence it can increase risk by lowering the profit efficiency indirectly. Further found that overall commercial banks are 53\% efficient and they can improve their profit efficiency by up to 47\%, the existing slum in profit gains.
\end{abstract}

Keywords: Financial Openness, Efficiency, Z-Score, Bank Risk.

\section{Introduction}

Financial Openness is normally stated as the opening up of financial markets of a domestic economy for foreign investors. The global financial market has seen rapid changes during the last couple of decades due to financial liberalization (Openness) across the world. This process of liberalization and financial deregulation has led to significant improvements in the flow of funds among the countries. Developing countries have liberalized their economic policies to get financial benefits from the flow of capital among economies. These liberalized economic policies pave the path for the sustainable economic growth of countries (Luo, Tanna, \& De Vita, 2016). 
A vital issue in decision making is how to deal with economic liberalization and how financial gain can be improved through mitigation of risk and increasing efficiency of the banking sector. The rapid flow of foreign capital in the domestic economies has a significant effect on the profit efficiency of local commercial banks (Agénor, 2001). It means that the profit efficiency of domestic commercial banks is always affected by financial openness as a result of such liberalization. It may increase or decrease by entering domestic banks in international business. How much profit efficiency of commercial banks is influenced by financial openness or bank risk and whether the significant impact of each variable on the other is positive or negative, is the problem addressed in the present study.

Risk and efficiency of the banking sector remained a favourite area of recent studies (Afza \& Asghar, 2017; Fang, Hasan, \& Marton, 2014; Laeven \& Levine, 2007) but relation of both variables of interest with financial openness yet remains to be addressed especially in the context of a single country. The aim of this study is to use default risk to check whether the risk is directly influenced by financial liberalization or incidentally plays a role, in the existing connection between financial openness and profit efficiency of domestic commercial banks.

The present study tends to hypothesize that the financial openness directly decreases the level of profit efficiency of the banking sector without changes in bank risk, while the risk is increased due to a decline in bank profit efficiency. It is a bi-dimension analysis in which one variable affects the other through each one of the two variables of the banking sector, efficiency, and risk, respectively, in Pakistan.

The main findings of the estimation indicate that financial openness is a variable that directly diminishes the profit efficiency of commercial banks without changes in bank default risk calculated as z-score. It implies that financial openness has a direct and negative impact on the profit efficiency of domestic banks working in the country. Z-score has an inverse relation with banking risk and higher values of $\mathrm{z}$-score show soundness of the bank. At the same time, the significant results show that financial openness upsurges bank risk incidentally, due to such a decrease in the profit efficiency of local commercial banks. Such results have not yet been considerably described in the prevailing literature specifically for Pakistan.

The objective of the study is to find out empirically the existing relationship among variables of the study, financial or trade Openness, banking risk and efficiency of conventional private banks working in Pakistan. By investigating separately, the direct and indirect impact, along with short and long effects of financial openness, default banking risk and bank's profit efficiency on each other, this study makes a fresh contribution in the existing literature and hopefully would be useful not only for researchers but also for the management of Pakistani banks in their decision making regarding profitability and risk of banks along with policy formation for long-run survival in competitive environment (Naveed, Ali, Iqbal, \& Sohail, 2020). The basic intent of the study is to examine the role of financial openness in determining bank risk and efficiency. The contextual setting of the study is provided by banking sector of Pakistan.

The current study fills the existing gap in the prevailing literature in two ways. First, mostly the studies available in existing literature have investigated financial openness, bank risk, and efficiency individually, or in cross border scenarios but in Pakistan, there is no considerable work found which has incorporated these variables Openness, Risk and Efficiency of the banking sector, in a single specific study (Naveed, Sindhu, \& Ali, 2020). Secondly, in the contextual framework specifically in the case of Pakistan, the research work conducted so far is very little and inconsiderable that has yet included these three important factors of the banking industry in a single step. Although cross country studies are useful for generalization of concept and theory testing it is less useful in the policymaking process.

The next sections of the study are organized as follows. Section 2 describes a review of previous literature. Section 3 consists of the methodology section and data description. Section 4 represents the results and Section 5 concludes. 


\section{Methodology}

\section{Data Collection and Sample}

The data is collected from the year 2008-2018, by first considering all domestic commercial (conventional) banks of Pakistan, available at the website of State Bank of Pakistan, then dropped certain banks due to the following reasons. (i) Banks for which data for the above mentioned period was missing. (ii) Banks that merged in some other bank or purchased by any other commercial bank. (iii) Islamic banks. The finalized sample consists of 143 bank-year observations, which includes 13 commercial banks working in Pakistan. All bank-level data was obtained from annual reports and income statements of commercial banks submitted to the central bank of the country. Data obtained for all commercial banks are represented in PKR million. The final sample covers private conventional banks to make a profit efficiency estimation more reliable and comparable for country-specific analysis and further realistic comparison of efficiency score of the sample banks. In addition to this, restricting the sample to conventional commercial banks makes an easy comparison due to the similarity of production technology, products, and services which makes the estimation of the model more realistic and comparable with country-specific research studies.

\section{GMM Estimation and Granger Causality}

The estimation starts with the ARDL Auto-Regressive Distributed Lag model to check for existing Granger causality among variables of the study, financial openness bank risk and profit efficiency of local commercial banks. Then Dynamic Penal GMM estimation of the ARDL model is used to find out the prevailing impact of financial openness on bank risk and efficiency of domestic commercial banks. The same model has been used by (Fiordelisi, Marques-Ibanez, \& Molyneux, 2011).

The Dynamic Panel GMM estimation of the ARDL model is written in equation form as follows:

$$
\begin{gathered}
\text { Efficiency }_{, t}=f_{1}\left(\text { Efficiency }_{i, \text { lag }}, \text { RISK }_{i, l a g}, F O P A K_{i, l a g}\right)+\varepsilon_{i, t} \\
R I S K_{i, t}=f_{1}\left(\text { RISK }_{i, l a g}, E f f \text { fiency }_{, l a g}, F O P A K_{i, l a g}\right)+\varepsilon_{i, t}
\end{gathered}
$$

Where $I$ represent the cross-section of banks at time $t$, while RISK is a bank risk calculated through z-score, Efficiency is the profit efficiency of commercial banks estimated through SFA and FOPAK denotes financial openness proxy as trade openness, and $\varepsilon_{i}$ is the random error term.

The above two equations are used to examine the interrelationship between financial openness, bank risk and profit efficiency of commercial banks. The first equation is established to check that any changes in bank risk results in changes in the profit efficiency of commercial banks. The second equation is proposed to investigate whether any changes in profit efficiency may result in a change in banking risk. It is a simultaneous estimation by GMM, which allows checking for prevailing endogeneity among variables of interest as explained above. It implies that financial openness can affect both counter variables risk and efficiency jointly, causing the reverse causality among variables of interest risk and efficiency.

In the present empirical estimation of the dynamic ARDL process, the study used two lags of each variable of interest and then estimated an AR (2) process as suggested by (Fiordelisi et al., 2011). First is to check that if the change in one variable granger causes the other one .and the Wald test is used to test for the null hypothesis assumed that the sum of two lags for $\mathrm{x}$ variable is equal to zero. The casual relationship among two variables is represented by a sum of lagged coefficients of the dependent variable. Then the analysis takes to check the long-run effects of change in one variable $\mathrm{x}$ on the other variable $\mathrm{y}$. It is determined from the estimated coefficients which represent the dynamics of both variable $\mathrm{x}$ and $\mathrm{y}$. 
In this estimation, the $\mathrm{x}$ variable is also the function of random error term, while at the same time the lag of $\mathrm{x}$ variable is correlated with error term, therefore the use of OLS is not viable anyway, which makes the results biased and inconsistent, hence the estimation moves to Sys GMM estimation for further analysis. In this scenario the system Generalized Method of movements (SYS-GMM) suggested by (Arellano \& Bover, 1995; Blundell \& Bond, 1998) and is used for estimation of dynamic penal data, and then apply the corrected standard errors form as suggested by (Windmeijer, 2005).

\section{Profit Efficiency Estimation}

Following the methodological approach which has been repeatedly used in recent studies (Gaganis \& Pasiouras, 2013; Luo et al., 2016), the present endeavor also employ the (SFA) Stochastic Frontier Analysis, to calculate the efficiency score of commercial banks operating in Pakistan, to further find out the prospective impact of financial openness and risk on the efficiency of private commercial banks. (Battese \& Coelli, 1995) model are applied for this purpose as applied in previous studies. This model not only allows the measure of inefficiency among the best efficient bank in the model but also incorporates the country as well as banking-related specific variables, which may directly cause the inefficiency of domestic commercial banks working in the economy.

While controlling for other specific variables such as asset diversification and diversification of income among different commercial banks, size of the bank, GDP growth in the country, such special arrangements allow examining the direct and indirect influence caused by financial openness on bank risk and profit efficiency while also considering the significant influence caused by bank risk in this relationship (Naveed, Saif, \& Sindhu, 2017). The empirical estimation of profit functions while taking the input prices and output prices as the independent variable are written below in the equation form.

Profit Model is represented in general form as under:

$$
\ln P B T_{i, t}=\pi\left(p_{i t}, w_{i t}, \beta\right)-u_{i t}+v_{i t}
$$

In the above equation, $P B T_{i, t}$, is the profit before tax of bank $\mathrm{i}$, at time $\mathrm{t}$, and $p_{i, t}$, is the vector of output prices while $\mathrm{d} w_{i} \mathrm{t}$, is the vector of input prices. $\beta$ is the vector of the unknown scalar which connects the input prices with outputs in a profit function. $v_{i, t}$ Shows the error term used in the model.

It is assumed that this error term is independent and identically distributed while $u_{i} \mathrm{t}$, is the inefficiency random error term which is also assumed to be independent however it not normally distributed, instead, it follows the truncated distribution with truncation at zero i.e. $N\left(m_{i, t}, \sigma_{i, t}^{2}\right)$, The same estimation has been used by (Gaganis \& Pasiouras, 2013; Luo et al., 2016) in their models.

Mean is defined as under:

$$
m_{i, t}=z_{i, t}, \delta
$$

Where $z_{i, t}$ is a vector of dependent variable which is the inefficiency term of a bank 'i', at the time 't', and $\delta$ is the vector of variable yet needs to be estimated. The study follows the Battese and Coelli (1995) model as followed by several studies, in which coefficients of equation (1) and equation (2) are estimated in single-step estimation by implying the maximum likelihood method.

In this way, the study investigates the significant influence caused by financial openness on risk and efficiency of domestic commercial banks working in the economy 


\section{Selection of Inputs and Output Prices}

The present research study implies the intermediation approach to finalize the input and output prices of variables as used in different previous research studies (Gaganis \& Pasiouras, 2013; Luo et al., 2016) . In this approach, banks are treated as intermediaries, which collect funds from depositors to convert them into a loan for the prospective borrower. In this process, there have been specified two output prices and three input prices. Output prices include p1 calculated as the ratio of interest earned by the bank divided by its amount of gross loans; $\mathrm{p} 2$ is calculated as the ratio of non-interest income divided by other earning assets. Input prices include $w 1$ calculated as the cost of funds for the loan; w2 refers to the cost of capital which is measured by overhead expenses of commercial banks, calculated as net of personal expenses divided by the book value of fixed assets. Third input w3 includes the cost of labour calculated as personal expenses divided by the total asset value of the bank.

The similar estimations have been implied by (Luo et al., 2016) in cross country evidence and (Afza \& Asghar, 2017) in a single country analysis for the efficiency of commercial banks of a domestic economy, where efficiency score was calculated through SFA for further analysis. Equity (EQ) is also used additionally as quasi-fixed input variable in the model of profit function to control for other bank's risk level differences as suggested by (Berger \& Mester, 1997), that since the equity is also a source of loans, failure to control this may lead to a scale biased result in calculation of inefficiency of a bank, therefore the input price 'EQ' is used to normalize the dependent variable.

\section{Empirical SFA Model}

While implying the SFA model, a multi-product trans-log function is applied to calculate the efficiency score of all commercial banks working in the country. It is based on the work of Taylor's extension frequently used in a number of previous studies. The trans-log function form allows for better flexibility for the evaluation of the efficiency frontier in the model.

By using the above-specified model, the efficiency score of all domestic commercial banks is calculated for further estimation to finally investigate the significant impact of financial openness on the risk and efficiency of local commercial banks.

Equation form of the above-specified model of empirical profit function is specified as under:

$$
\begin{aligned}
\frac{\ln P B T}{w 3}=\beta_{0}+\beta_{1} & \ln \left(\frac{p 1}{w 3}\right)+\beta_{2} \ln \left(\frac{p 2}{w 3}\right)+\beta_{3} \ln \left(\frac{w 1}{w 3}\right)+\beta_{4} \ln \left(\frac{w 2}{w 3}\right)+\beta_{5} \frac{1}{2}\left(\ln \left(\frac{p 1}{w 3}\right)\right)^{2} \\
& +\beta_{6} \ln \left(\frac{p 1}{w 3}\right) \ln \left(\frac{p 2}{w 3}\right)+\beta_{7} \frac{1}{2}\left(\ln \left(\frac{p 2}{w 3}\right)\right)^{2}+\beta_{8} \frac{1}{2}\left(\ln \left(\frac{w 1}{w 3}\right)\right)^{2}+\beta_{9} \ln \left(\frac{p 1}{w 3}\right) \ln \left(\frac{w 1}{w 3}\right) \\
& +\beta_{10} \ln \left(\frac{p 2}{w 3}\right) \ln \left(\frac{w 1}{w 3}\right)+\beta_{11} \frac{1}{2}\left(\ln \left(\frac{w 2}{w 3}\right)\right)^{2}+\beta_{12} \ln \left(\frac{p 1}{w 3}\right) \ln \left(\frac{w 2}{w 3}\right) \\
& +\beta_{13} \ln \left(\frac{p 2}{w 3}\right) \ln \left(\frac{w 2}{w 3}\right)+\beta_{14} \ln \left(\frac{w 1}{w 3}\right) \ln \left(\frac{w 2}{w 3}\right)+\beta_{15} \ln (E Q)+\beta_{16} \frac{1}{2}(\ln (E Q))^{2} \\
& +\beta_{17} \ln (E Q) \ln \left(\frac{p 1}{w 3}\right)+\beta_{18} \ln (E Q) \ln \left(\frac{p 2}{w 3}\right)+\beta_{18} \ln (E Q) \ln \left(\frac{w 1}{w 3}\right)+\beta_{18} \ln (E Q) \ln \left(\frac{w 2}{w 3}\right) \\
& -u_{i, t}+v_{i, t}
\end{aligned}
$$

Here the followed approach was suggested by (Pasiouras, Tanna, \& Zopounidis, 2009) to deal with negative values of profit declared by several commercial banks in their financial statements submitted to the central bank of the country. In this approach, a constant value is added to the negative value of the profit before tax to convert into an absolute value. In this process, the negative value of bank profit plus one is added to its original value to obtain an absolute value of profit (Luo et al., 2016; Pasiouras et al., 2009). 


\section{Inefficiency Determinants}

The empirical function is developed to find out the inefficiency determinants of Pakistani commercial banks, to further examine the expected impact of financial openness and risk on the mean inefficiency of local commercial banks while controlling for other bank-level variables.

The regression model mentioned in the equation form is given below.

$$
\begin{aligned}
m_{i, t}=\beta_{0} F O P A K & +\beta_{1} R I S K+\beta_{2} G D P+\beta_{3} S I Z E+\beta_{4} I N F+\beta_{5} A S S E T D I V \\
& +\beta_{6} I N C D I V+\beta_{7} D 11+\beta_{8} D 10+\beta_{9} D 09+\beta_{10} D 08+\beta_{11} D 07 \\
& +\beta_{12} D 06+\beta_{13} D 05+\beta_{14} D 04+\beta_{15} D 03+\beta_{16} D 02+\beta_{17} D 01
\end{aligned}
$$

Where FOPAK represents the measurement of financial openness for Pakistan, RISK is a variable of bank risk calculated through z-score. In the above estimation, some other related variables are also used as control variables for specific bank-level and country-level differences, such as macroeconomic conditions measured by (GDP) i.e. growth rate in the country, Inflation (INF) reflects rate of inflation in the country, (SIZE) is the size of bank, (ASSETDIV) Asset Diversification and (INCMDIV) Income Diversification among banks, as used in comparable studies (Gaganis \& Pasiouras, 2013; Luo et al., 2016). In addition, year dummies (D01-D11) have been used to control time effects. In this way, the random inefficiency term will be calculated and used in the above estimation process. Such control variables have also been used in some recent studies such as (Delis, Iosifidi, \& Tsionas, 2017).

\section{Measure of Variables}

\section{Financial Openness}

Trade openness indicates that countries having no issues regarding import and export their products without any limitation. Imports and Exports are considered as a tool for the measurement of advanced economies. Trade openness has introduced new horizons of competition for products in several countries. Now economies are encouraged to analyze the comparative advantages of their products (Zhang, Zhu, \& Lu, 2015).

The de facto measure of financial openness is the most used proxy in previous literature. It is a trading volume estimated by imports plus exports as a share of GDP for that country. In the present study, it has been used as the proxy for financial openness as a percentage of total imports and exports to the GDP of a country, taken from the World Bank data for Pakistan available at The Global Economy.

\section{Bank Risk}

Bank risk variable is estimated by using z-score as a proxy for bank risk. It has been used by several previous research studies (Fang et al., 2014; Luo et al., 2016). The basic principle behind z-score is that it relates the equity of a bank to its variability of returns. The variability of returns is measured through the standard deviation of return on assets (ROA). From this justification, it can be interpreted that a bank will become insolvent if its level of equity comes to zero (Li, Tripe, \& Malone, 2017). This type of default risk has been used by previous studies where z-score is used as a proxy of default risk. Therefore in the present estimation also used z-score as a proxy for the bank's default risk in the country.

ZSCORE estimation is mentioned below:

$$
\mathbb{Z}=\{(R O A+E / A) / O ́(R O A)\}
$$


Where ' $\mathrm{Z}$ ' is the $\mathrm{z}$-score, ROAं represents the rate of return on total assets, $E / A$ is the ratio of equity and assets, Ó(ROA) shows the standard deviation estimated for return on assets. Thus $Z$-score may be assumed to be a number of standard deviation by which returns may fall from mean to reduce the equity of a bank, for example, (Fang et al., 2014) described that the higher value of z-score indicates that a bank is more sound and stable.

\section{Control Variables}

By using the estimation of (Fiordelisi et al., 2011) and some other related studies, the present endure also includes some bank level-specific control variables that may affect the mean inefficiency of domestic commercial banks working in the economy. These variables includes Diversification among assets of the bank (ASSETDIV), measured as "1- [(Net Loans - Other Earning Assets) / Total Earning Assets]"; Income diversification among diverse sources of income of several commercial banks in the same economy (INCMDIV), calculated as "1- [(Net Interest Income - Other Operating Income) / Total Operating Income]"; and bank size (SIZE) proxy used by calculating natural log of total assets of the banks. Inflation is the rate of Inflation in the country. In addition, the study also controls for other macroeconomic conditions using GDP as our control variable for the estimation and reliability of results.

\section{Results}

The result section stars with descriptive statistics which include a brief overview of included variables.

\section{Descriptive Statistics}

Before going in-depth of this endeavor, a little view of descriptive statistics is represented in table1, where two outputs and three inputs prices have been used in the SFA model. Natural log of all prime frontier variables including profit before tax and equity have been divided by w3, the third input price for banks.

Table 1 Descriptive Statistics

\begin{tabular}{|c|c|c|c|c|c|}
\hline Variable Name & Obs. & Mean & SD & Minimum & Maximum \\
\hline Frontier Variables & 3 & & & & \\
\hline $\ln (\mathrm{PBT} / \mathrm{W} 3)$ & 143 & 12.7649 & 3.1712 & 3.16 & 16.18 \\
\hline $\ln (\mathrm{P} 1 / \mathrm{W} 3)$ & 143 & 2.6113 & 0.6342 & -3.58 & 3.87 \\
\hline $\ln (\mathrm{P} 2 / \mathrm{W} 3)$ & 143 & 1.0623 & 0.5443 & -0.06 & 2.60 \\
\hline $\ln (\mathrm{W} 1 / \mathrm{W} 3)$ & 143 & 4.6258 & 2.0856 & 1.11 & 13.11 \\
\hline $\ln (\mathrm{W} 2 / \mathrm{W} 3)$ & 143 & 3.4900 & 0.6002 & 1.98 & 5.45 \\
\hline $\ln (\mathrm{EQ})$ & 143 & 9.1446 & 0.5893 & 7.60 & 0.56 \\
\hline \multicolumn{6}{|l|}{ Inefficiency Terms: } \\
\hline Zscore & 143 & 1.6333 & 1.3610 & -5.97 & 5.41 \\
\hline Fopak & 143 & 32.007 & 2.9792 & 25.32 & 35.68 \\
\hline Asset diversification & 143 & 0.58167 & 0.5807 & -2.25 & 1.57 \\
\hline Income diversification & 143 & 0.79874 & 0.3101 & -5.28 & 1.91 \\
\hline Size & 143 & 12.635 & 1.0453 & 8.65 & 14.73 \\
\hline Inflation & 143 & 9.6454 & 4.8275 & 2.52 & 20.32 \\
\hline GDP & 143 & 4.0254 & 1.4852 & 0.36 & 5.82 \\
\hline
\end{tabular}

Note: Variables have already been described above in methodology section.P1 and P2 are two outputs while W1, W2, and W3 are input prices used in the SFA model.

Inefficiency terms include financial openness, bank risk proxies by $\mathrm{z}$-score, income and asset diversification, bank size, inflation and GDP growth as controlled variables. FOPAK represents the measure of financial openness; RISK is the level of default risk for a bank calculated through $\mathrm{z}$-score. Some other variables are also included in the model as control variables for specific bank-level differences, 
such as macroeconomic conditions measured by $(G D P)$, Inflation as the rate of inflation in the country (INF), size of the bank calculated by taking natural log of the total assets (SIZE), Diversification among assets of the bank (ASSETDIV), and Diversification among income of the bank (INCMDIV) as used in some recent studies.

\section{Correlation Analysis}

Table 2 represents the correlation coefficients for the variables used in the study. Before addressing the results of the ARDL and system GMM model, correlation analysis provides an opportune to have a brief look at the overall strength of the relationship among variables in a summarized form. As shown in the correlation table, financial openness is negatively correlated with $\mathrm{Z}$-score and it is significant at a 95 percent confidence level. It means that bank risk is negatively associated with financial openness and an inverse relationship exists between two variables.

Table 2: Correlation Analysis

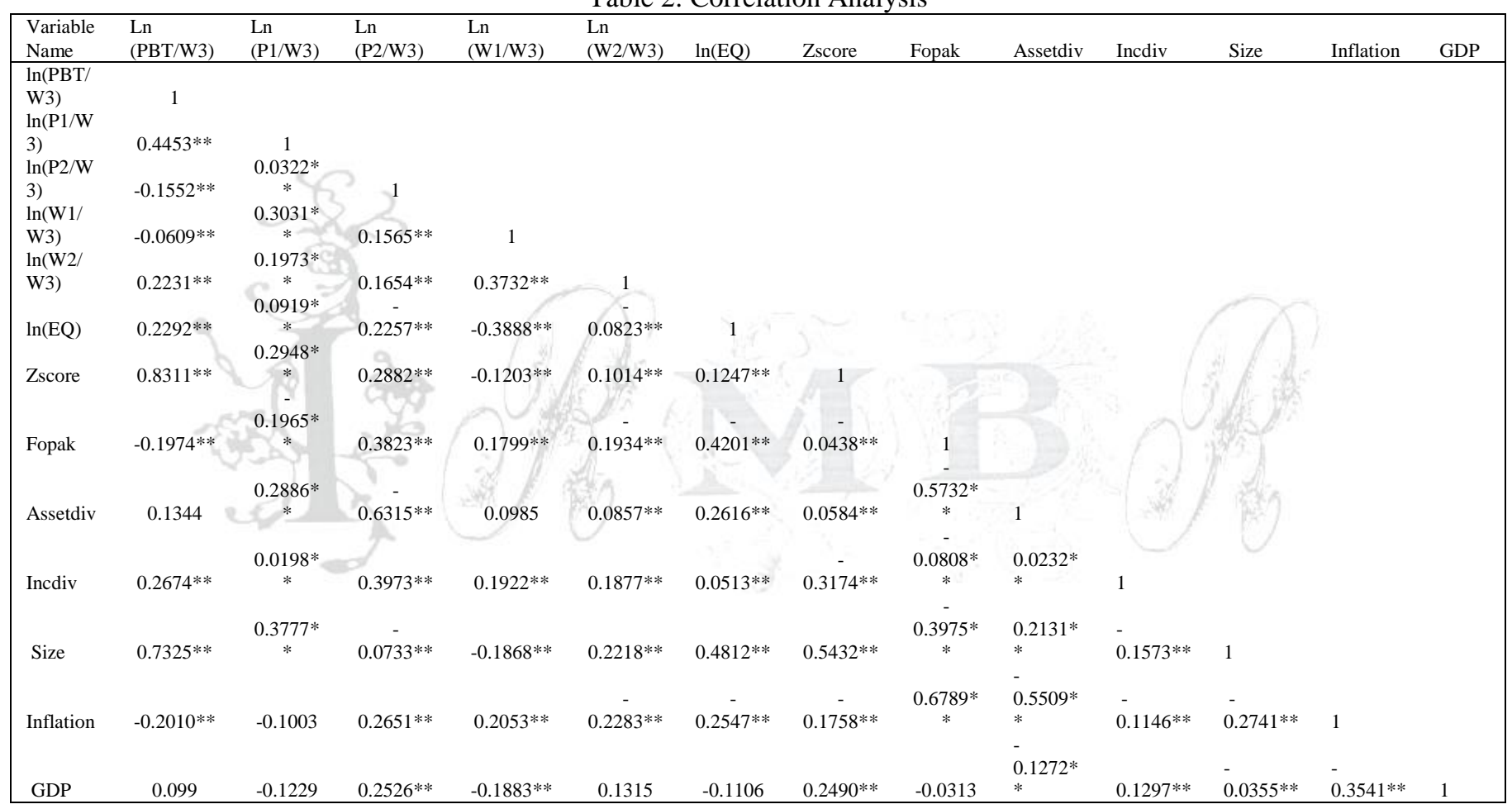

** Represents the result significance at $95 \%$ confidence level.

Further financial openness is also has a significant association with efficiency variables. It means that financial openness while taking into account the variable of risk, has a negative influence on the profit efficiency of domestic commercial banks which would be further confirmed through further analysis of GMM results. Z-score is also significantly correlated with efficiency variables. It has a negative association with income diversification among banks and the inflation rate of the country, while it is positively related to asset diversification, size and GDP growth of the country. Overall control variables have significant correlation coefficients with bank risk and financial openness. 


\section{Efficiency Analysis}

The efficiency score of the complete sample of commercial banks working in Pakistan is presented in Table 3 . The obtained results have been shown in mean values averaged by group and years, which also include standard deviation, minimum value, and maximum value.

Efficiency score analysis shows that the mean profit efficiency of all sample banks presented a declining trend since the year 2008 to 2012. Afterward, the efficiency score shown continues improvements until the year 2018. Overall the mean efficiency of all samples is 0.530 . It means that local commercial banks can improve their average profit efficiency by $47 \%$ as compared to the best practicing bank in the sample. It also implies that average Pakistani commercial banks are earning $47 \%$ lower profit than the best profit earning bank in the sample, which requires special attention by the management while making policies. These results can be broadly compared with some recent studies such as (Luo et al., 2016) in cross country evidence and (Afza \& Asghar, 2017)in the country-specific analysis.

Secondly, the first declining and then improving trend in profit efficiency over time shows that commercial banks are moderating their profit earning strategies in a competitive environment to remain profitable and as a result, they are improving their profits. The mean efficiency score in the year 2013 to 2018 shows that commercial banks in Pakistan have improved their profit efficiency by more than $50 \%$ in the mentioned period, but even then yet they are $47 \%$ less efficient as compared to the best profit earning bank in the study.

However, it can be derived from the strand that commercial banks working in Pakistan are rapidly improving their profit efficiency over time and have the further capability to improve their profit efficiency with cost-cutting and profit-oriented strategies.

Table 3: Efficiency Score for all Sample

\begin{tabular}{|c|c|c|c|c|c|}
\hline Year & Obs. & Mean & St. Dev & Minimum & Maximum \\
\hline & & & & & \\
2008 & 13 & 0.6495 & 0.3210 & 0.1462 & 0.9997 \\
2009 & 13 & 0.5253 & 0.3702 & 0.0001 & 0.9997 \\
2010 & 13 & 0.3643 & 0.2832 & 0.0013 & 0.9513 \\
2011 & 13 & 0.3563 & 0.3219 & 0.0006 & 0.9982 \\
2012 & 13 & 0.3852 & 0.3183 & 0.0005 & 0.9995 \\
2013 & 13 & 0.4644 & 0.2513 & 0.0011 & 0.9993 \\
2014 & 13 & 0.4903 & 0.2450 & 0.0006 & 0.8089 \\
2015 & 13 & 0.4821 & 0.2950 & 0.0000 & 0.9996 \\
2016 & 13 & 0.6162 & 0.2398 & 0.0113 & 0.8968 \\
2017 & 13 & 0.7291 & 0.2126 & 0.2780 & 0.9994 \\
2018 & 13 & 0.7704 & 0.3107 & 0.0003 & 0.9996 \\
TOTAL & 143 & 0.5303 & 0.3128 & 0.0004 & 0.9997 \\
\hline
\end{tabular}

Table 4 presents the mean efficiency score of 13 private banks working in Pakistan, which were finally selected to be included in the study. The results indicate that MCB Bank is the most efficient bank among the entire sample with the highest mean efficiency score of 0.914. Allied Bank Ltd is the second most efficient bank in the entire sample with a mean efficiency score of 0.710 . This implies that the large banks are the most profit earning banks in the banking sector of Pakistan but medium and small banks can also compete for large banks with better allocation of resources and cost-cutting policies, for example, Bank AlHabib Ltd. is not included in five large banks but its efficiency score is at number three in the strange with a mean efficiency score 0.706 . 
United Bank Ltd. is also a large bank of the country but its mean efficiency score 0.6462 indicates that this bank can further improve its efficiency by approximately $35 \%$ by focusing its different profit earning strategies, developing competitive products and cost-cutting policies. All other banks including HBL can also increase their capability of earning more profit and increase their profit efficiency by controlling their leakages of income, batter allocation of their resources and taking some more risk to earn more profit. Summit Bank being a new and small bank is more behind in the sample with the lowest mean efficiency score 0.1580 . The possible reason for the low-efficiency score for this bank is loss declared in previous years. The management of this bank should focus on their available competitive products, their advances portfolio and investment in high return projects. All other banks in the sample can also review their policies to increase their profit efficiency to be remaining more competitive in the banking sector.

Table 4 Bank wise efficiency score

\begin{tabular}{|lrrrrr|}
\hline Bank Name & Obs. & Mean & St. Dev & Minimum & Maximum \\
\hline Allied Bank Ltd. & 11 & 0.7103 & 0.1841 & 0.4118 & 0.9994 \\
Askari Bank Ltd. & 11 & 0.3343 & 0.3061 & 0.0044 & 0.9996 \\
Bank AlFalah Ltd. & 11 & 0.4648 & 0.2776 & 0.0785 & 0.9993 \\
Bank AlHabib Ltd. & 11 & 0.7067 & 0.1296 & 0.5538 & 0.9996 \\
Faysal Bank Ltd. & 11 & 0.3860 & 0.3093 & 0.1221 & 0.9996 \\
Habib Bank Ltd. & 11 & 0.5885 & 0.1523 & 0.4758 & 0.9997 \\
Habib Metro Bank Ltd. & 11 & 0.6469 & 0.1486 & 0.4771 & 0.9991 \\
JS Bank Ltd. & 11 & 0.3268 & 0.3576 & 0.0003 & 0.9994 \\
MCB Bank Ld. & 11 & 0.9148 & 0.0773 & 0.8089 & 0.9995 \\
Soneri Bank Ltd. & 11 & 0.5640 & 0.3218 & 0.0531 & 0.9995 \\
Standard Charted Bank & 11 & 0.4462 & 0.3292 & 0.0382 & 0.9996 \\
Summit Bank Ltd. & 11 & 0.1580 & 0.3167 & 0.0003 & 0.9997 \\
United Bank Ltd & 11 & 0.6462 & 0.1949 & 0.3913 & 0.9995 \\
\hline
\end{tabular}

\section{Dynamic ARDL results}

Results obtained through the dynamic penal ARDL model are portrayed in table 5 mentioned below. Table 4 shows the marks obtained from the Dynamic Penal Auto-Regressive Distributed lagged Model used in this study. There have been used two lags of each variable i.e Financial Openness, Banking Risk (calculated as Z-score) and the efficiency level of local commercial banks, to check whether a change in one unit of independent variable equally causes the change in the dependent variable in a short-run and long-run causal scenario. Short-run coefficients are significant at a 95 percent confidence level, which confirms the existence of the co-integration of variables. Although the short-run coefficient of $\mathrm{z}$-score at $2^{\text {nd }}$ lag is insignificant it is significant at first difference. The estimated $\mathrm{F}$ value indicates that the overall model is significant having granger causality among variables which is also confirmed by further GMM results.

Table 5 ARDL Results

\begin{tabular}{|llll|}
\hline D efficiency & Coef. & Std. Err. & $\mathrm{p}$ value \\
\hline L2_efficiency & -0.1574 & 0.0871 & 0.0430 \\
D_zscore & 0.0805 & 0.0147 & 0.0000 \\
L2_zscore & 0.0131 & 0.0152 & 0.3890 \\
D_fopak & -0.0227 & 0.0097 & 0.0200 \\
L2_fopak & -0.0184 & 0.0134 & 0.0130 \\
F value: 0.0000 & R-squared : 0.3246 & No. of Obs. : 117 & \\
\hline
\end{tabular}

Note: Efficiency is the dependent variable.

P-value shows the results significant at a $95 \%$ confidence level. 


\section{System GMM Results}

In Table 5 the profit efficiency is the dependent variable while in table 6 , bank risk is the dependent variable. The system GMM estimation is conducted to check for prospective endogeneity in independent variables along with the probability of reverse causality among the z-score and efficiency of domestic banks. The analysis is conducted with two lags for each variable. The obtained results also report the longrun effects and sum of lags to check for the total effects of one variable on another. Sargan and Hansen's test is applied to confirm the validity of the instruments used in the model while Arellano Bond test checks for the existence of serial correlation among variables. Wald test is applied and reported to check the null hypothesis, described as there granger causality does not exist among variables of the study. If the p-value of the Wald test is less than 0.05 , it rejects the null hypothesis that one variable does not Granger cause the other. The reported p-value of the Wald test also confirms that Granger Causality exists among variables. Regression is conducted while taking two lags of each dependent and independent variables. The sum of lags shows the total effects of each variable while long-run coefficients show the long-run relationship among variables of the study.

The Sys-GMM results of penal data illustrate that Financial Openness (fopak) negatively Granger causes the dependent variable. Although the first effect of fopak is negative and insignificant it is significant at the second lag. The sum of lags and the values of long-run coefficients also show that financial openness has a significant inverse collision on the profit efficiency of local banks. While on the other hand, banking risk measured by z-score, has positive effects on the profit efficiency of private commercial banks. Coefficients of zscore are positive but insignificant while long-run coefficients are positive and significant at $5 \%$ level of significance.

Table 6: System GMM Results

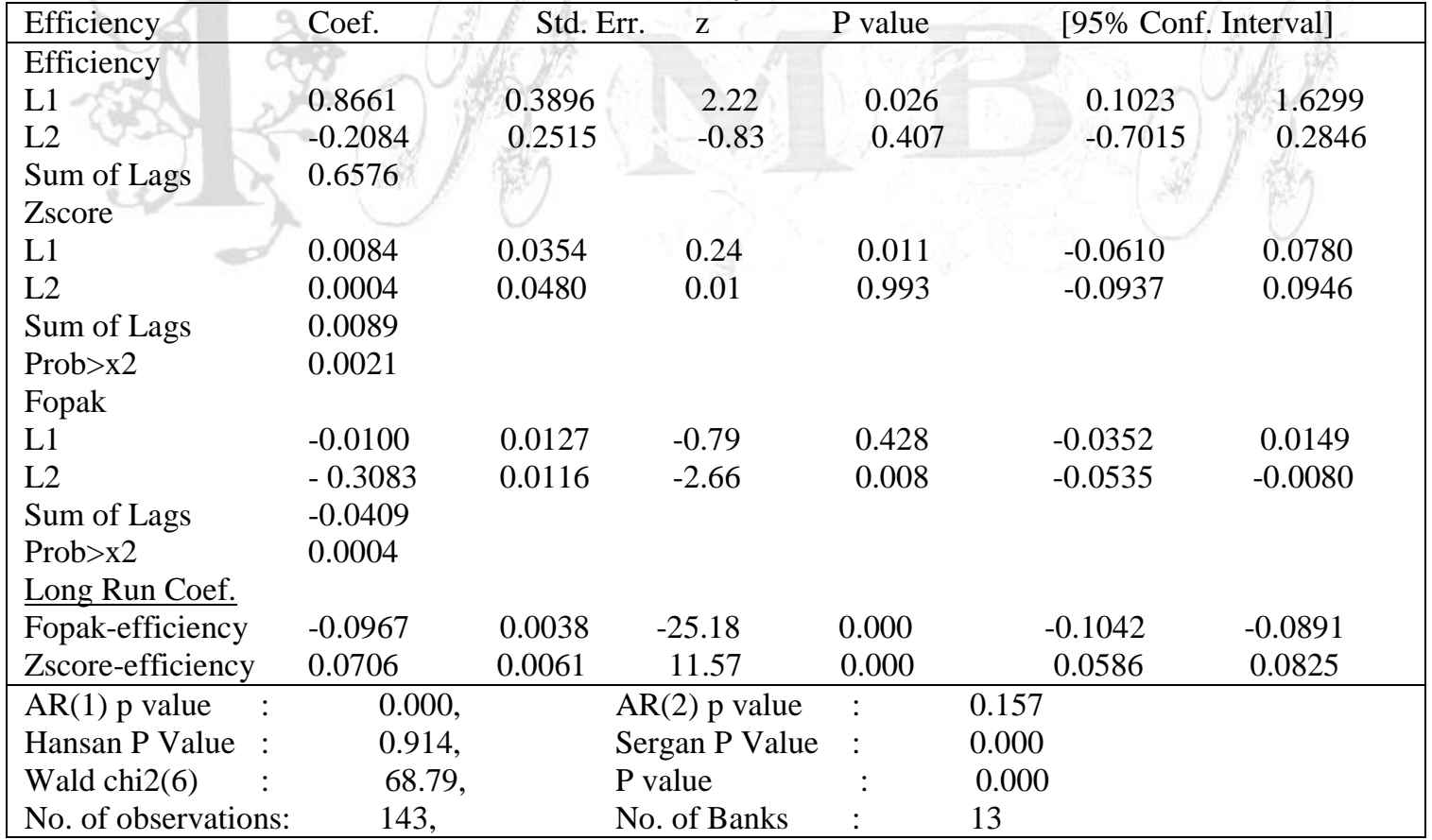

Note: Dynamic penal data, two step system GMM results, where Efficiency is the dependent variable.

The result indicates that the higher value of bank soundness leads to a significant increase in the profit efficiency of banks because the risk is measured by the inverse of $\mathrm{z}$-score value. The higher level of $\mathrm{z}$-score score indicates the lower level of bank risk. It implies that lower bank profit efficiency may result in higher 
banking risk as to the inverse of (zscore) or vice versa. The long run effects of fopak on efficiency are negative and much stronger than that of $\mathrm{z}$-score on the efficiency, but both are significant at $95 \%$ confidence level. The similar results were found in some comparable studies for example (Luo et al., 2016).

Table 7 shows the results where z-score is a dependent variable, financial openness (fopak) and efficiency are the independent variables. Efficiency is positively related to zscore at first lag while negative at a second lag. Coefficients are significant at first lag but insignificant at a second lag. The sum of lag effects is negative but insignificant. Long-run effects are also positive.

Table 7 System GMM Results

\begin{tabular}{|c|c|c|c|c|c|c|}
\hline Zscore & Coef. & Std. Err. & $\mathrm{z}$ & $\mathrm{P}$ value & \multicolumn{2}{|c|}{ [95\% Conf. Interval] } \\
\hline \multicolumn{7}{|l|}{ Zscore } \\
\hline L1 & 0.0831 & 0.4902 & 0.17 & 0.048 & -0.8776 & 1.0439 \\
\hline L2 & 0.0658 & 0.1880 & 0.35 & 0.026 & -0.3027 & 0.4344 \\
\hline Sum of Lags & 0.0559 & & & & & \\
\hline \multicolumn{7}{|l|}{ Efficiency } \\
\hline L1 & 0.9672 & 2.8023 & 1.42 & 0.017 & -1.5252 & 9.4596 \\
\hline L2 & -1.9029 & 1.2659 & -1.50 & 0.130 & -4.3842 & 0.5783 \\
\hline Sum of Lags & -0.9357 & & & & & \\
\hline Prob $>x 2$ & 0.817 & & & & & \\
\hline \multicolumn{7}{|l|}{ Fopak } \\
\hline L1 & 0.0484 & 0.0929 & 0.52 & 0.602 & -0.1336 & 0.23059 \\
\hline $\operatorname{cst}$ & 0.0051 & 0.0403 & 0.13 & 0.898 & -0.0738 & 0.08425 \\
\hline \multicolumn{7}{|l|}{ Sum of Lags } \\
\hline \multicolumn{7}{|l|}{ Prob $>x 2$} \\
\hline \multicolumn{7}{|l|}{ Long Run coef. } \\
\hline Efficiency-Zscore & 0.8311 & 0.0070 & 11.41 & 0.035 & 0.0666 & 0.0942 \\
\hline Fopak-Zscore & 0.0311 & 1.8603 & 0.98 & 0.325 & -1.8151 & 5.4774 \\
\hline $\operatorname{AR}(1) \quad:$ & 0.000 , & & $\overline{A R}(2)$ & & 0.229 & \\
\hline Hansen P Value : & 0.991, & & Sergen $\mathrm{F}$ & Value : & 0.018 & \\
\hline Wald chi2(6) : & 116.20 & & $P$ value & : & 0.000 & \\
\hline Number of Banks: & 13 & & Number & of observatio & ns: 143 & \\
\hline
\end{tabular}

Note: Dynamic penal data, two step system GMM results, where Z-score is the dependent variable.

The result indicates that profit efficiency positively granger causes z-score. It implies that an increase in bank soundness may precede an increase in profit efficiency of the bank due to the inverse relation of $\mathrm{z}$ score with bank risk Financial openness also positively granger causes the dependent variable at both lags and with long run effects but results are insignificant at all coefficients. It means that financial openness has no significant influence on z-score directly however it can influence bank risk indirectly through a change in profit efficiency. The results support the above findings in Table 5 which implies that a bank may increase its profits by taking more risk.

In both Tables 6 and 7, the results indicate that risk is positively associated with efficiency while financial openness negatively Granger causes efficiency. While p-value confirms that the overall model is significant at 5 percent level of significance. The Sargan and Hansen test confirm the soundness of applied instruments in the model. Wald test also confirms the existence of Granger causality among variables of the study. The values of Arellano Bond also confirm that serial correlation does not exist among variables.

\section{Inefficiency Determinants}

Results reported in Table 8 are obtained from regression determinants of the inefficiency of commercial banks calculated through the SFA approach using the Battese and Coilli model specified to find out the 
prospective collision caused by financial openness and risk on the efficiency of local commercial banks operating in Pakistan. Financial openness and risk are included as independent variables. Some other control variables are also used for country-specific analysis such as income diversification among banks, asset diversification, and size of the bank, GDP growth, and inflation in the country. The results show that financial openness is significant and positively associated with inefficiency. It indicates that financial openness conversely has an inverse collision on the efficiency of commercial banks. Z-score has a significant inverse influence on inefficiency which means that it has a positive association with efficiency. It implies that commercial banks can enhance their profit efficiency by taking more risks.

All other control variables including asset diversification, income diversification, size, and inflation have a positive association with mean inefficiency. The only GDP has a negative association with inefficiency. Among these variables, only income diversification and the prevailing rate of inflation in the country have a significant influence on the mean inefficiency of the commercial banks. It means that banks with more income and asset diversified portfolio enjoy better profit efficiency.

Table 8 Inefficiency Determinants

\begin{tabular}{|c|c|c|c|c|c|c|}
\hline Inefficiency & Coef. & Std. Err. & $\mathrm{t}$ & $P$ value & \multicolumn{2}{|c|}{ [95\% Conf. Interval] } \\
\hline Fopak & 0.0207 & 0.0087 & 2.38 & 0.019 & 0.0035 & 0.0380 \\
\hline Zscore & -0.1206 & 0.0138 & -8.68 & 0.000 & -0.1481 & -0.0931 \\
\hline Assetdiv & 0.0030 & 0.0262 & 0.12 & 0.908 & -0.0489 & 0.0550 \\
\hline Incdiv & 0.0396 & 0.0136 & 2.90 & 0.004 & 0.0126 & 0.0667 \\
\hline Size & 0.0084 & 0.0216 & 0.39 & 0.698 & -0.0344 & 0.0513 \\
\hline Inflation & 0.0095 & 0.0056 & 1.68 & 0.096 & -0.0017 & 0.0208 \\
\hline GDP & -0.0144 & 0.0140 & -1.03 & 0.304 & -0.0423 & 0.0133 \\
\hline Log Likeliho & 127.771 & $y$ & & & & \\
\hline F value & 0.0000 & & & & & \\
\hline
\end{tabular}

The insignificant and positive impact of size on mean inefficiency indicates that the size is optimistically linked with an efficiency level of local commercial banks. F value also indicates that the overall model is significant at 5 percent level of significance. $F$ value rejects the null hypothesis that all of the regression coefficients are equal to zero. The results obtained therein are also similar to those found in comparable studies.

\section{Conclusion}

Considering 13 private commercial banks operating in Pakistan, final data covers the time phase from 2008-2018, the estimation is conducted to cater to these investigations in the following way. First to check that whether the financial openness has a direct influence on the efficiency level of domestic commercial banks or otherwise the profit efficiency of commercial banks is not directly influenced by financial openness through changes in bank risk, the present endure starts from the ARDL model. Since the efficiency of domestic banks is also a factor that can influence the banking risk, the estimation is started by using dynamic simultaneous models of equations through system GMM on the efficiency of domestic private banks and banking risk calculated as z-score jointly, where financial openness is the explanatory variable. Then, the efficiency score is estimated by implying the "stochastic frontier analysis" (SFA) approach. Financial openness is estimated by using a proxy of trade openness as used in several previous studies. Banking risk is calculated through Z-score as calculated in several previous studies.

The main results of this study show that financial openness does not directly influence the banking risk calculated as z-score, but it affects the banking risk indirectly by decreasing the profit efficiency of 
domestic commercial banks in Pakistan, such results have yet not been considerably reported in the prevailing literature and research work done so far in the banking region of Pakistan. It can be conceived from significant values of coefficients and strong relationship among variables that financial openness negatively granger causes the profit efficiency of domestic commercial banks of the economy hence it has a direct negative impact on the level of profit efficiency. While profit efficiency granger causes the z-core positively this means that lower profit efficiency may precede in a higher level of bank risk and vice versa. Since the financial openness has a negative influence on the profit efficiency of commercial banks and profit efficiency is negatively related to the bank risk, therefore it is further conceived that financial openness has an indirect positive impact on bank risk. It can increase bank risk by lowering the profit efficiency level of domestic banks due to its direct negative association with profit efficiency. On the other hand, if domestic banks are able to cater to a higher level of profit efficiency even in liberalization, their risk level would be obviously decreased consequently. It is a key factor to be considered in the decisionmaking process executed by banks managements to mitigate risk and maintain a higher level of profit efficiency even in the liberalization era while entering into the international banking business (Naveed, Ali, et al., 2020). In other words, by taking higher risk through investment in profitable opportunities created as a result of financial openness in the economy, domestic banks may enjoy better financial incentives due to trade-off between financial openness and bank risk respectively.

Limitations of the study include that the endeavour moves from general to specific but the finalized data seems insufficient for complete analysis and testing the results found by previous researchers. By investigating separately, the direct and indirect impacts of financial openness, default banking risk and profit efficiency level, on each other, this study hopefully would be useful not only for researchers but also for the management of Pakistani banks in their decision making regarding profitability and risk. It is proposed for the future research that the same estimation could be done on Islamic bank of the country separately, to further confirm the reliability of results and also to compare these results with efficiency score of Islamic banks of Pakistan as Islamic banking is growing with a significant pace and a sizable share in the total banking industry of Pakistan. Further, a deep analysis is recommended for an overall comparison of all public and private commercial banks through efficiency analysis.

\section{References}

Afza, T., \& Asghar, M. J.-e.-K. A. (2017). Efficiency of Commercial Banks in Pakistan: Application of SFA and Value Added Approach. Argumenta Oeconomica, 1(38), 195-220.

Agénor, P.-R. (2001). Benefits and costs of international financial integration: theory and facts: The World Bank.

Arellano, M., \& Bover, O. (1995). Another look at the instrumental variable estimation of errorcomponents models. Journal of econometrics, 68(1), 29-51.

Battese, G. E., \& Coelli, T. J. (1995). A model for technical inefficiency effects in a stochastic frontier production function for panel data. Empirical economics, 20(2), 325-332.

Berger, A. N., \& Mester, L. J. (1997). Inside the black box: What explains differences in the efficiencies of financial institutions? Board of Governors of the Federal Reserve System working paper(1997-10).

Blundell, R., \& Bond, S. (1998). Initial conditions and moment restrictions in dynamic panel data models. Journal of econometrics, 87(1), 115-143.

Delis, M., Iosifidi, M., \& Tsionas, M. G. (2017). Endogenous bank risk and efficiency. European Journal of Operational Research, 260(1), 376-387.

Fang, Y., Hasan, I., \& Marton, K. (2014). Institutional development and bank stability: Evidence from transition countries. Journal of Banking \& Finance, 39, 160-176.

Fiordelisi, F., Marques-Ibanez, D., \& Molyneux, P. (2011). Efficiency and risk in European banking. Journal of Banking \& Finance, 35(5), 1315-1326.

Gaganis, C., \& Pasiouras, F. (2013). Financial supervision regimes and bank efficiency: International evidence. Journal of Banking \& Finance, 37(12), 5463-5475. 
Laeven, L., \& Levine, R. (2007). Is there a diversification discount in financial conglomerates? Journal of financial economics, 85(2), 331-367.

Li, X., Tripe, D. W., \& Malone, C. B. (2017). Measuring bank risk: An exploration of z-score. Available at SSRN 2823946.

Luo, Y., Tanna, S., \& De Vita, G. (2016). Financial openness, risk and bank efficiency: Cross-country evidence. Journal of Financial Stability, 24, 132-148.

Naveed, M., Ali, S., Iqbal, K., \& Sohail, M. K. J. S. A. J. o. B. S. (2020). Role of financial and nonfinancial information in determining individual investor investment decision: a signaling perspective.

Naveed, M., Saif, O. B., \& Sindhu, M. I. (2017). Impact of Bank Competition on Bank Liquidity Creation: Empirical Evidence from GCC and ASEAN Region.

NAVEED, M., SINDHU, M. I., \& ALI, S. J. S. o. A. E. (2020). Role of Financial and Non-Financial Information in Shaping Trading Behavior: A Retail Investor's Perspective. 38(3).

Pasiouras, F., Tanna, S., \& Zopounidis, C. (2009). The impact of banking regulations on banks' cost and profit efficiency: Cross-country evidence. International Review of Financial Analysis, 18(5), 294-302.

Windmeijer, F. (2005). A finite sample correction for the variance of linear efficient two-step GMM estimators. Journal of econometrics, 126(1), 25-51.

Zhang, C., Zhu, Y., \& Lu, Z. (2015). Trade openness, financial openness, and financial development in China. Journal of International Money and Finance, 59, 287-309.

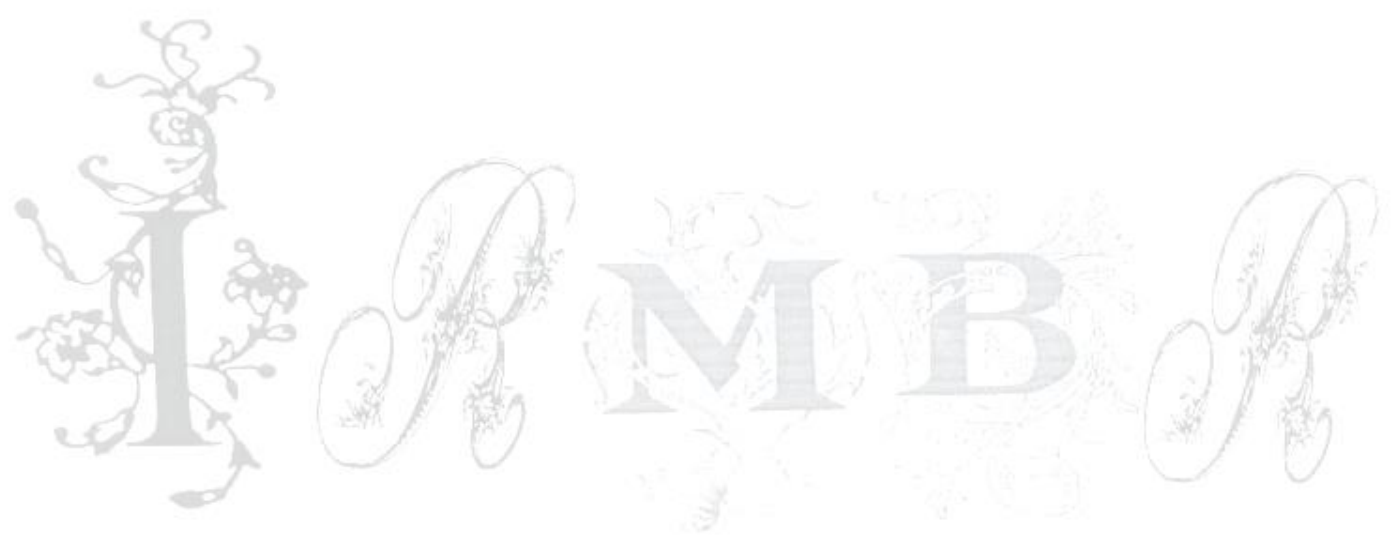

